de Beaux's Briefsteller für Kaufleute

Zweite Stufe Band 1

\title{
Deutsche Handelskorrespondenz
}

für

Handels- und Realschulen

von

\section{Prof. Th. de Beaux}

Officier de l'Instruction publique

Lektor an der Handelshochschuie und Oberlehrer a. D.

der Öffentlichen Handelslehranstalt zu Leipzig

\section{LEIPZIG}

G. J. Göschen'sche Verlagshandlung 
Alle Rechte, insbesondere das thersetzungsrecht, von der Verlagshandlung vorbehalten. 